\title{
Unusual presentation of acute pulmonary embolus presenting with inferior ST elevation
}

\author{
Amar Mistry, Nalin Natarajan, Shahana Hussain, Zakariyya Vali
}

Cardiovascular Medicine, University Hospitals of Leicester NHS Trust, Leicester, UK

Correspondence to Dr Amar Mistry, amarmistry@nhs.net

Accepted 19 July 2018

\section{Check for updates}

(C) BMJ Publishing Group Limited. No commercial re-use. See rights and permissions. Published by BMJ.

\begin{tabular}{l}
\hline To cite: Mistry A, \\
Natarajan N, Hussain S, et al. \\
BMJ Case Rep Published \\
Online First: [please \\
include Day Month Year]. \\
doi:10.1136/bcr-2018- \\
226063
\end{tabular}

\section{DESCRIPTION}

A 67-year-old woman presented with a 6-hour history of dull, inspiratory chest pain and shortness of breath that had subsided on arrival to hospital. She denied any history of coronary artery disease and had no veno-thromboembolic risk factors. Her semirecumbent blood pressure was $94 / 50 \mathrm{~mm} \mathrm{Hg}$, and oxygen saturations were $98 \%$ on room air. Chest X-ray was unremarkable. The initial ECG demonstrated sinus tachycardia only. She later developed further chest pain with dynamic $1 \mathrm{~mm}$ ST segment elevation in lead III (figure 1A). In addition, there was ECG evidence of S1Q3T3 pattern, and troponin was $3444 \mathrm{ng} / \mathrm{mL}$. An urgent bedside transthoracic echocardiogram supported a diagnosis of acute pulmonary embolus (APE) as opposed to acute ST elevation myocardial infarction (figure 1B-D). It showed a D-shaped left ventricle in both phases of the cardiac cycle reflecting right ventricular volume and pressure overload and a dilated inferior vena cava. The patient was commenced on low molecular weight heparin and an urgent CT pulmonary angiogram confirmed the presence of bilateral pulmonary emboli. As the patient was not hypotensive (systolic blood pressure $>90$ ), primary reperfusion with systemic thrombolysis was not immediately indicated.

ECG changes occur in 70\%-80\% of APE with common features including sinus tachycardia, right bundle branch block, 'S1Q3T3' pattern and/or precordial T-wave inversion. ${ }^{1}$ Right precordial and anteroseptal ST elevation have been described in

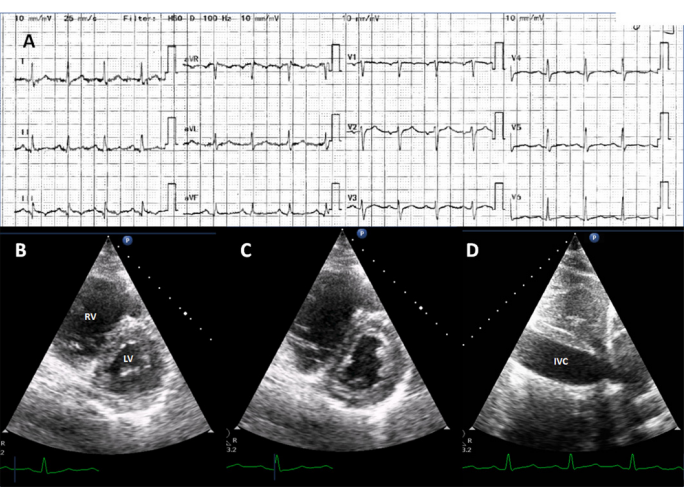

Figure 1 (A) Twelve-lead ECG demonstrating ST elevation in lead III and S1Q3T3 pattern. (B) Transthoracic echocardiogram in the parasternal short axis at midventricle demonstrating right ventricular pressure overload at end-systole, (C) volume overload at enddiastole and (D) inferior vena cava dilatation in the subcostal view. IVC, inferior vena cava; LV, left ventricle; $\mathrm{RV}$, right ventricle. case reports, but ST-elevation confined to the inferior leads is an unusual feature that has rarely been reported..$^{1-3}$ These inferior ST changes are thought to be a reflection of transmural right ventricle (RV) ischaemia resulting from a combination of hypotension, hypoxaemia, pulmonary artery hypertension and a catecholamine surge. ${ }^{2}$ The dynamic nature of ST elevation corresponding with the exacerbation of symptoms that occurred in this patient may reflect increasing RV ischaemia and the potential for a worse outcome with haemodynamic instability. ${ }^{2}$

If APE is not considered at the outset, patients may unnecessarily undergo emergency coronary angiography primarily on the basis of the ST elevation. This may show no occlusive coronary disease or confound the actual diagnosis if coronary artery stenosis that is not significantly flow limiting is revealed. The result would be a delayed diagnosis of APE following subsequent invasive angiographic assessment or CT pulmonary angiography.

In the event of a high clinical suspicion of APE but with ST elevation, a transthoracic echocardiogram should be performed if available to support the diagnosis. This case highlights the importance of recognising APE as a cause of dynamic inferior ST elevation, thereby avoiding inappropriate investigations, misdiagnosis and an adverse outcome.

\section{Learning points}

Acute pulmonary emboli can present with the unusual finding of inferior ST elevation.

- In the context of ST elevation, an echocardiogram can help differentiate myocardial infarction from acute pulmonary embolus when there is clinical doubt.

Contributors All authors had a significant contribution to this report. AM was involved in the management of the patient, participated in the literature review and writing of the report. NN participated in the literature review and writing of the report. SH and ZV participated in the writing of the report.

Funding The authors have not declared a specific grant for this research from any funding agency in the public, commercial or not-for-profit sectors.

Competing interests None declared.

Patient consent Obtained.

Provenance and peer review Not commissioned; externally peer reviewed.

\section{REFERENCES}

1 Omar HR. ST-segment elevation in V1-V4 in acute pulmonary embolism: a case presentation and review of literature. Eur Heart J Acute Cardiovasc Care 2016;5:579-86. 
2 Zhan ZQ, Wang CQ, Nikus KC, et al. Electrocardiogram patterns during hemodynamic instability in patients with acute pulmonary embolism. Ann Noninvasive Electrocardiol 2014;19:543-51.
3 Emren SV, Arıkan ME, Senöz O, et al. Acute pulmonary embolism mimicking inferior myocardial infarction. Turk Kardiyol Dern Ars $2014 ; 42: 290-3$

Copyright 2018 BMJ Publishing Group. All rights reserved. For permission to reuse any of this content visit http://group.bmj.com/group/rights-licensing/permissions.

BMJ Case Report Fellows may re-use this article for personal use and teaching without any further permission.

Become a Fellow of BMJ Case Reports today and you can:

- Submit as many cases as you like

- Enjoy fast sympathetic peer review and rapid publication of accepted articles

- Access all the published articles

- Re-use any of the published material for personal use and teaching without further permission

For information on Institutional Fellowships contact consortiasales@bmjgroup.com

Visit casereports.bmj.com for more articles like this and to become a Fellow 